\title{
Implikasi Covid-19 Terhadap Pendapatan Hotel Di Kawasan Sembalun Lombok Timur (Studi Kasus Pada Rinjani Hill Hotel)
}

\author{
Tama Krisnahadi $^{1}$,Baiq Herdina Septika ${ }^{2}$, Menik Aryani ${ }^{3}$ \\ Universitas Pendidikan Mandalika \\ Email: tama.wahda@gmail.com¹,dinarajabi30@gmail.com²,menikaryani81@gmail.com³
}

\begin{abstract}
Abstrak. Pandemi covid-19 membuat pertumbuhan perekonomian dunia menjadi lambat. Kondisi ini dialami oleh seluruh dunia terutama dalam industri pariwisata khususnya perhotelan. Penelitian ini bertujuan untuk mengetahui implikasi covid-19 terhadap pendapatan hotel di kawasan Sembalun Lombok Timur khususnya Rinjani Hill Hotel serta untuk mengetahui upaya yang dilakukan oleh manajemen Rinjani Hill Hotel bangkit dari keterpurukan akibat pandemic covid-19. Penelitian ini merupakan penelitian kualitatif dengan desain studi kasus tunggal dimana tehnik pengumpulan data dilakukan dengan beberapa metode antara lain metode observasi, wawancara, dan dokumentasi. Alat analisis yang digunakan dalam penelitian ini adalah teknik analisis data interaktif dengan tahapan yaitu : pengumpulan data, reduksi data, penyajian data, penarikan kesimpulan dan verifikasi. Berdasarkan hasil observasi lapangan, penelitian dan pembahasan, diperoleh data bahwa pada triwulan pertama sejak pandemi covid-19 menghantam Indonesia pada umumnya dan Lombok pada khusunya sangat berdampak terhadap operasional Rinjani Hill Hotel, akan tetapi sejak dilonggarkannya kebijakan pemerintah terkait Work From Home (WFH) tingkat kunjungan hotel mulai membaik dan terlihat ada peningkatan jumlah kunjungan dibandingkan beberapa bulan sebelum pandemi covid-19 mulai mewabah hal ini berdampak langsung dari sisi pendapatan hotel itu sendiri. Penerapan protokol kesehatan pada hotel merupakan salah satu cara didalam mempertahankan loyality konsumen.
\end{abstract}

Kata kunci : Hotel, Pendapatan, Implikasi Covid-19

\section{PENDAHULUAN}

Menurut World Health Organization (WHO) Corona virus merupakan virus yang menginfeksi sistem pernapasan. Infeksi virus ini disebut Covid-19. Virus ini menyerang sistem pernapasan pada manusia. Dimana pada awal tahun 2020 tepatnya pada bulan maret virus ini mewabah hampir diseluruh dunia. Virus ini dapat menyebabkan gangguan pada sistem pernapasan, pneumonia akut, sampai pada kematian bagi penderitanya. Pandemi ini bermula dari negeri Cina yaitu Kota Wuhan pada akhir tahun 2019 dan melanda hampir semua negara yang ada di dunia termasuk Indonesia.

Di Indonesia sendiri penderita covid-19 mulai ditemukan pada awal maret 2020 dimana sampai dengan awal April 2020 telah terkonfirmasi 2.956 kasus positif covid-19, dimana 240 kasus di antaranya meninggal dan 222 kasus sembuh dinyatakan sembuh.
Pandemic covid-19 ini sudah tersebar hampir di 32 provinsi dari total 34 provinsi yang ada di Indonesia.

(https://id.wikipedia.org/wiki/Pandemi_korona virus_di_Indonesia).

Dengan adanya pandemi ini tentunya tidak hanya memberikan dampak pada kesehatan saja tetapi juga kepada perekonomian di Indonesia. Dampak covid-19 sangatlah besar dimana virus ini menyebabkan kelumpuhan perekonomian Indonesia secara menyeluruh terlebih untuk sektor pariwisata. Dikutip dari CNN Indonesia, Menteri Keuangan Republik Indonesia mengatakan bahwa proyeksi pertumbuhan ekonomi Indonesia tidak akan melebihi 2,3\%. Bahkan, dalam situasi terburuk, ekonomi Indonesia bisa minus hingga $0,4 \%$ hal ini akan berdampak langsung terhadap perekonomian Indonesia terutama tingkat inflasinya. Penyebab dari hal 
ini diantaranya adalah turunnya konsumsi dan investasi yang dilakukan oleh masyarakat dan juga pemerintah saat pandemi covid-19.

Pandemi covid-19 di Indonesia ini tentunya berdampak pada semua sektor perekonomian terutama pada industri pariwisata. Dikutip dari CNN Indonesia, ketua umum PHRI yang menyatakan bahwa bahwa Industri pariwisata khususnya di Indonesia sudah menjadi salah satu sektor yang menjanjikan dalam peningkatan taraf hidup masyarakat dimana sektor pariwisata menjadi sektor yang menjanjikan bagi peningkatan perekonomian di Indonesia, karena memiliki banyak keunggulan serta menjadi salah satu penyumbang peningkatan ekonomi terbesar untuk Indonesia termasuk devisa bagi negara.

Lombok merupakan salah satu pulau dengan berbagai destinasi wisata yang indah. Pada tahun 2015 lombok memperoleh 2 penghargaan pada World Halal Travel Summit di Abu Dhabi Uni Emirat Arab. Penghargaan yang diperoleh yaitu World's Best Halal Honeymoon dan. World's Best Halal Honeymoon Destination. Pulau Lombok terkenal dengan pemandangannya yang hijau alami serta kaya dengan beranekaragam budaya dan tempat-tempat pariwisata. Sejak memperoleh penghargaan itu kunjungan wisatawan semakin meningkat baik untuk wisatawan lokal maupun mancanegara.

Pada tahun 2018 industri pariwisata Lombok mengalami penurunan hal ini disebabkan karena terjadi gempa bumi di wilayah Lombok. Aktivitas pariwisata mati suri selama gempa bumi tersebut dan terjadi penurunan jumlah wisatawan yang datang ke Lombok. Setelah itu Lombok mencoba bangkit dan melakukan perbaikan pada industri pariwisata yaitu dengan menggiatkan lagi promosi wisata ke Lombok.

Pada tahun 2020 industri pariwisata di Lombok kembali mengalami mati suri karena adanya pandemic covid-19 yang membuat penurunan drastis terhadap jumlah kunjungan wisatawan lokal maupun mancanegara. Hal ini menyebabkan beberapa hotel di wilayah Lombok khususnya daerah sembalun sepi pengunjung. Salah satunya adalah Rinjani Hill Hotel, sejak diberlakukannya kebijakan terkait social distancing dan phisycal distancing oleh pemerintah pusat maupun daerah hotel tersebut mengalami sepi kunjungan wisatawan. Beberapa hotel mengambil kebijakan untuk menutup sementara dan merumahkan karyawannya. Keputusan sulit ini diambil oleh manajemen hotel demi dapat bertahan di masa pandemi ini.

\section{Rumusan Masalah}

Berdasarkan uraian pada latar belakang dapat dirumuskan permasalahan sebagai berikut

1. Bagaimana implikasi covid-19 terhadap pendapatan Rinjani Hill Hotel

2. Bagaimana upaya yang dilakukan oleh Rinjani Hill Hotel untuk bangkit dari keterpurukan akibat pandemi covid-19.

\section{METODE PENELITIAN}

Penelitian ini merupakan penelitian kualitatif studi kasus yang mengkaji implikasi covid-19 terhadap pendapatan Rinjani Hill Hotel dikawasan Sembalun Lombok Timur. Penelitian studi kasus merupakan strategi yang lebih cocok bila pokok pertanyaannya berkenaan dengan pencarian penyebab seperti "bagaimana" atau "mengapa", dimana peneliti hanya memiliki sedikit peluang untuk mengontrol peristiwaperistiwa yang akan diselidiki (Afifudin dan Saebani,2009). Studi kasus sering digunakan secara luas dalam penelitian ilmu-ilmu sosial, baik pada displin-disiplin tradisional (Psikologi, Sosiologi, Ilmu Politik dan Antropologi) disamping itu juga digunakan dalam penelitian yang berkaitan dengan perencanaan dan pengembangan kawasan/wilayah, kebijakan dan ilmu manajemen.

\section{Desain Penelitian}

Desain penelitian yang digunakan dalam peneltian ini adalah studi kasus tunggal karena hanya akan mengkaji tentang implikasi covid-19 terhadap pendapatan hotel di kawasan 
Sembalun Lombok Timur khususnya Rinjani Hill Hotel.

Kasus

Pemilihan kasus didasarkan pada pemilihan secara purposive yaitu dipilih dengan pertimbangan dan tujuan tertentu. Dipilihnya kasus ini karena banyaknya informasi yang beredar terkait pendapatan hotel yang hampir secara keseluruhan mengalami penurunan dalam hal pedapatan hotel baik dari sisi penyewaan kamar, restaurant dan segala fasilitas hotel yang mendatangkan pendapatan bagi hotel.

\section{Informan}

Dalam peneltian kualitatif peneliti adalah instrumen utama, sedangkan informan kunci (key informan) boleh peneliti sendiri atau orang lain yang dapat memberikan informasi mendalam tentang masalah yang diteliti. Penentuan informan dilakukan secara "purposive sampling", yaitu dipilih dengan pertimbangan dan tujuan tertentu yang dipandang dapat memberikan informasi dan data secara maksimal, dalam hal ini adalah pihakpihak yang terlibat langsung dalam operasional hotel sampai menunjukkan tingkat kejenuhan informasi. Adapun key informan dalam penelitian ini adalah General Manajer Rinjani Hill Hotel, Marketing Manajer dan Public Relation serta Accounting Manager. Penentuan key informan ini dipilih berdasarkan pengetahuan dan keterlibatan manajemen dalam hal operasional hotel.

\section{Tehnik Pengumpulan Data}

Tehnik pengumpulan data yang digunakan dalam penelitian ini meliputi:

1. Observasi lapangan, yaitu pengumpulan data dengan mengamati proses kegiatan yang ada di Rinjani Hill Hotel.

2. Wawancara mendalam (indepth interview), yaitu pengumpulan data dengan melakukan wawancara mendalam terhadap informan kunci.

3. Dokumentasi, yaitu pengumpulan data yang berasal dari sumber sekunder berupa dokumen-dokumen yang terkait dengan penelitian ini

\section{Analisis Data}

Uji validitas data dilakukan dengan teknik triangulasi data. Analisis data menggunakan teknik analisis data interaktif dengan tahapan yang meliputi pengumpulan data, reduksi data, penyajian data, penarikan kesimpulan dan verifikasi. Untuk tahapan prosedur penelitian ini dimulai dari persiapan, pengumpulan data, analisis data dan penyusunan laporan penelitian.

\section{Validitas dan Reliabilitas}

Dalam penelitian kualitatif, suatu data dikatakan valid jika tidak ada perbedaan data atau temuan antara yang dilaporkan peneliti dengan yang sesungguhnya terjadi pada objek yang diteliti (Sugiyono, 2006).

Kualitas penelitian ini dirancang dengan pendekatan studi kasus yang ditentukan oleh validitas dan reliabilitasnya dari hasil penelitia (Yin, 2002). Dalam penelitian studi kasus uji validitas terdiri dari: (1) validitas konstruk, (2) validitas internal, (3) validitas eksternal, dan (4) realiabilitas (Yin, 2002). Dalam penelitian ini validitas konstruk dicapai melalui: (a) wawancara dilakukan pada informan yang berkompeten terhadap pendapatan dan operasional Rinjani Hill Hotel sehingga data yang diberikan benar-benar akurat, (b) melakukan kajian dengan teori sebelumnya, yang memungkinkan peneliti melakukan cek dan kroscek baik ide dengan peneliti sebelumnya maupun dengan hasil temuan, dan (c) menggunakan multi sumber bukti atau triangulasi, yang memungkinkan peneliti mendapatkan pemahaman yang lebih mendalam tentang fenomena yang diteliti. Validitas internal diperoleh dengan melakukan inferensi "sebab" dan "akibat" yang lebih luas berdasarkan bukti yang ditemukan pada saat penelitian (Afifudin,2009). Validitas eksternal merupakan kemampuan dalam menggeneralisir temuan, diperoleh melalui prosedur pemilihan lingkungan penelitian studi kasus dan informan. Sedangkan reliabilitas dalam penelitian ini diperoleh dengan tersedianya dokumentasi dan prosedur yang digunakan dalam penelitian studi 
Jurnal Ilmu Sosial dan Pendidikan

http://ejournal.mandalanursa.org/index.php/JISIP/index

Terakreditasi Peringkat 5 (No. SK: 85/M/KPT/2020)

kasus (Sugiyono,2006) baik dalam pengumpulan dan penganalisaan data yang meliputi protokol studi kasus, database dari studi kasus serta transkrip wawancara dan bukti pendukung lainnya.

\section{HASIL DAN PEMBAHASAN Hasil Penelitian \\ Gambaran lokasi Penelitian}

Rinjani Hill Hotel merupakan salah satu hotel kelas melati yang ada di Kecamatan Sembalun Lombok Timur yang letaknya tepat di kaki gunung rinjani yang ada di Pulau Lombok. Hotel ini berada di pinggir jalan tepatnya di jalan Sembalun Raya yang berdiri diatas areal tanah seluas 40 are. Hotel ini mulai beroperasi sejak tahun 2016. Rinjani Hill Hotel memiliki 12 fasilitas kamar yang terdiri dari 8 unit kamar dengan single bad dan 4 kamar double bad dengan tarif Rp. 350.000- dan Rp.450.000- saat weekend atau hari libur. Dimana setiap kamar difasilitasi dengan lemari, kamar mandi, closed duduk, water hitter, kursi serta televisi. Disamping itu juga Rinjani Hill memiliki restaurant sekaligus menjadi room meeting bagi para tamu yang membutuhkan, disamping itu juga pemandangan gunung yang menakjubkan serta fasilitas lain menjadi salah satu yang menjadi ketertarikan wisatawan untuk menginap di Rinjani Hill Hotel.

\section{Data Primer}

Data primer yang dianalisis merupakan hasil observasi peneliti yang dilakukan pada Rinjani Hill Hotel. Dimana data primer tersebut merupakan hasil wawancara peneliti dengan key informan yang terdapat pada Rinjani Hill Hotel yang tentunya memiliki kompetensi didalam penyampaian informasi terkait dengan penelitian ini. Adapun key informan yang dihadirkan dalam peneltian ini adalah:

a. L. Ferdi Yaunur Rahman sebagai General Manajer Rinjani Hill Hotel,

b. Affan Gafar sebagai Marketing Manajer and Public relation dan

c. L. Dwi Efri Reza sebagai Accounting Manager
Vol. 4. No. 4 November 2020

p-ISSN: 2598-9944 e- ISSN: 2656-6753

\section{Wawancara mendalam (In-depth Interview) dengan General Manager Rinjani Hill Hotel}

Penunjukan General Manager sebagai salah satu narasumber karena dianggap sebagai informan utama yang mengimplementasikan dari semua kegiatan yang ada di Rinjani Hill Hotel, disamping itu juga sebagai pihak yang berpengaruh besar di dalam semua kegiatan operasional Rinjani Hill Hotel. General manager dianggap dapat memberikan informasi mengenai dampak covid-19 secara menyeluruh terhadap pendapatan hotel.

Berikut adalah hasil wawancara penulis dengan General Manager Rinjani Hill Hotel berkaitan dengan pendapatan hotel sebelum dan sesudah pandemi. Di awal wawancara penulis menanyakan terkait peran general manager dalam mengelola semua aktifitas yang ada pada Rinjani Hill Hotel termasuk di dalamnya pendapatan hotel itu sendiri. Berdasarkan hasil pengakuan Bapak Lalu Ferdi Yaunur Rahman sebagai general manager terkait perannya dalam mengelola semua aktifitas Rinjani Hill Hotel, menurut GM Rinjani Hill "Tugas saya sebagai GM Rinjani Hill Hotel yaitu mengorganisasikan agar semua operasional baik dari divisi terbawah sampai dengan divisi atas dapat berjalan dengan baik dan maksimal. Dimana peran seorang GM mengkoordinasikan semua aktifitas yang ada di hotel dengan manajer-manajer yang yang terkait dengan bidangnya masing-masing baik itu bagian marketing, accounting, public relation bahkan sampai ke bagian house keeping yang ada di dalam hotel". Pada kesempatan yang sama peneliti bertanya terkait jumlah karyawan yang ada di Rinjani Hill Hotel, terkait pertanyaan tersebut Bapak Lalu menjawab bahwa "jumlah karyawan yang ada di Rinjani Hill Hotel berjumalah sekitar 20 orang termasuk cleaning service."

Selanjutnya peneliti menanyakan terkait dampak covid-19 terhadap kunjungan hotel yang tentunya berdampak langsung terhadap pendapatan hotel dan pada kesempatan ini narasumber menambahkan bahwa "Sampai saat ini kami tidak melihat adanya perubahan 
yang signifikan terkait kunjungan tamu hotel yang tentunya akan berdampak terhadap pendapat hotel secara langsung, hanya saja saat diterapkannya kebijakan pemerintah terkait Work From Home (WFH) saat itu sangat terasa sekali pengurangan kunjungan tamu hotel apalagi saat itu kawasan wisata sembalun diisolasi dari kunjungan wisatawan hal ini terjadi sekitar pertengahan bulan maret sampai dengan bulan mei pada saat itu operasinal perusahaan pincang sebelah dimana biaya operasional hotel harus tetap berjalan hal ini membuat kita sebagai manajemen dari hotel menekan pengeluaran khusunya terhadap karyawan hotel dengan pembagian shift kerja".

Peneliti selanjutnya menanyakan terkait seberapa besar dampak covid-19 ini terhadap pendapatan hotel jika dibandingkan dengan pendapatan sebelum pandemi pada kesempatan ini narasumber menambahkan bahwa "Kunjungan tamu hotel yang menginap disaat pandemic khususnya setelah berubahnya kebijakan pemerintah terkait WFH secara umum tingkat kunjungan wisatawan relatif mendekati stabil dimana pada periode desember 2019 sampai dengan maret 2020 total jumlah kunjungan tamu yang menginap sebesar 274 kamar sedangkan saat terjadinya pandemic khususnya sejak adanya kelonggaran kebijakan pemerintah terkait aturan WFH jumlah kunjungan tamu hotel bertambah pada periode juni 2020 sampai dengan september 2020 dimana jumlah pengunjung hotel yang menyewa kamar berjumlah 243 kamar dimana saat weekend atau akhir pekan kamar hotel bisa terisi semua".

Kemudian peneliti bertanya terkait kunjungan tamu yang meningkat disaat pandemic covid-19, narasumber menambahkan bahwa "Peningkatan kunjungan tamu hotel disekitar wilayah Sembalun pada umumnya kemungkinan disebabkan karena ketertarikan pengunjung terhadap wisata alamnya dan udara yang ada disekitar sembalun disamping itu juga protokol kesehatan tetap dijalankan bagi semua pengunjung hotel termasuk karyawan dan manajemen hotel itu sendiri dengan menyediakan hand sanitizer, sabun, wadah cuci tangan di pintu hotel, lounge, lobi hotel dan setiap kamar yang ada di Rinjani Hill Hotel".

Pada kesempatan terakhir peneliti menanyakan terkait pendapatan yang dihasilkan saat pandemi virus ini apakah bisa memenuhi keseluruhan dari biaya operasional hotel atau tidak dari pertanyaan peneliti GM menyatakan bahwa "Secara keseluruhan pendapatan hotel Alhamdulillah dapat memenuhi semua operasional hotel secara keseluruhan termasuk saat terjadinya isolasi di kawasan Sembalun periode maret sampai dengan awal mei. Hal ini dapat tertutupi sejak diberlakukaknya kebijakan pemerintah terkait $\mathrm{WFH}^{\prime}$. Selanjutnya peneliti bertanya terkait kiat-kiat dan strategi dari manajemen hotel untuk menjaga kelangsungan hidup perusahaan disaat pandemi berlangsung pada kesempatan ini GM menambahkan bahwa "Untuk strategi marketing kami menerapakan berbagai macam strategi marketing mix dimana selain penerapan protocol kesehatan di dalam lingkungan hotel kami juga melakukan pemasaran melalu media sosial yang ada seperti traveloka, booking.com, agoda.com, m.tiket.com serta media yang lainnya disamping itu juga peningkatan dari sisi pelayanan terhadap tamu hotel lebih diutamakan bahkan terkadang pemasaran hotel kami melalui Word of mouth dimana tamu hotel yang sudah berkunjung di Rinjani Hill Hotel menceritakan mengenai pengalaman mereka saat berkunjung di hotel kami kepada teman-temannya sehingga hotel kami menjadi temapt tujuan menginap bagi mereka saat berkunjung ke sembalun".

Wawancara mendalam (In-depth Interview) dengan Marketing Manajer sekaligus sebagai Public Relation

Narasumber kedua yang dipilih oleh penulis adalah Marketing Manager sekaligus sebagai Public Relation, hal ini dikarenakan beliau sebagai pihak yang menjalankan kegiatan terkait promosi, strategi pemasaran hotel kepada pelanggan serta hubungan dengan konsumen sehingga tercipta layality konsumen yang baik. 
Disamping itu juga marketing manajer memiliki kaitan yang erat dengan konsumen dalam relationship in touch langsung dengan tamu Rinjani Hill Hotel serta memberikan pelayanan yang lebih kepada tamu hotel yang sudah menjadi pelanggan tetap. Penulis berasumsi bahwa pihak ini merupakan ikut berpengaruh besar dalam membantu keefektifan pelaksanaan kegiatan customer relationship management sebagai pembuat strategi dalam hal pemasaran hotel disaat pandemi..

Berikut adalah hasil wawancara peneliti terhadap marketing manajer dan public relation berkaitan dengan customer relationship management yang terjalin dalam Rinjani Hill Hotel guna menciptakan loyalty customer.

Pada kesempatan ini peneliti memulai proses wawancara dengan manajer marketing dan public relation terkait dengan program customer relationship seperti apa yang dilakukan selama ini oleh pihak manajemen hotel. Dalam menanggapi pertanyaan dari peneliti, Bapak Affan Gafar selaku manajer marketing dan PR menjelaskan bahwa "Relationship merupakan dasar didalam melakukan interaksi baik dengan konsumen dan juga dengan sesama karyawan Rinjani Hill Hotel. Hubungan atau relationship yang baik dengan sesama karyawan antar departemen pada Rinjani Hill Hotel merupakan modal bagi manajemen hotel dalam memberikan pelayanan terbaik untuk konsumen kita. Dalam melakukan custumer relationship khususnya dengan konsumen kami menggunakan berbagai media komunikasi dalam menjalin komunikasi yang baik dengan konsumen kami, terkadang bagi konsumen yang sudah menjadi pelanggan kami biasanya kami memberikan diskon special bagi mereka diakhir pekan”.

Selanjutnya peneliti melanjutkan pertanyaan terkait apakah ada perbedaan didalam penerapan customer relationship sebelum dan saat terjadinya pandemi. Pada pertanyaan ini manajer marketing menjelaskan bahwa "Untuk penerapan custumer relationship sebelum dan saat pandemic ini tidak ada perubahan, kami tetap melakukan sesuai SOP yang telah ada".

Selanjutnya peneliti menanyakan terkait sejauh mana keberhasilan customer relationship yang sudah dilakukan saat pandemic ini apakah memberikan dampak positif terhadap kunjungan hotel serta tingkat kesulitan dalam penerapan customer relationship dengan konsumen disaat pandemic berlangsung. Pada kesempatan ini manajer marketing mejelaskan bahwa "Alhmadulillah penerapan costumer relationship kepada konsumen tidak mengalami kendala yang berarti dimana kita melakukan komunikasi dengan konsumen kita melalui telephone, WhatsApp dan sebagainya bahkan ada beberapa konsumen kami yang bertanya mengenai keadaan di Lombok pada umumnya dan sembalun pada khusunya terkait dengan pandemic yang sedang berlangsung dan kami memberikan informasi sesuai dengan keadaan yang sebenarnya terlebih saat ini penerbangan domestic sudah mulai lancar hal ini juga tentu berdampak terhadap pendapatan hotel kami.".

Wawancara mendalam (In-depth Interview) dengan Accountig Manager.

Penunjukan accounting manager sebagai salah satu narasumber oleh peneliti karena bagi peneliti seorang accounting manajer dianggap sebagai informan yang dapat memberikan informasi terkait keadaan keuangan hotel hubungannya dengan biaya opersioanl hotel secara keseluruhan.

Berikut adalah hasil wawancara penulis dengan accounting manajer Rinjani Hill Hotel berkaitan dengan pendapatan hotel sebelum dan sesudah pandemic. Diawal wawancara penulis menanyakan terkait tugas pokok dan fungsi dari accounting manager, pada kesempatan ini acoounting manajer menjelaskan bahwa "Sebagai accounting manager pada Rinjani Hill Hotel saya bertugas untuk mencatat seluruh transaksi keuangan, dan membuat laporan keuangan hotel baik pemasukan dan pengeluaran dan melaporkanya kepada general manager dan ouner dari Rinjani Hill Hotel”. 
Pada kesempatan yang sama pula peneliti mengajukan pertanyaan terkait dengan pendapatan hotel sebelum dan saat pandemic covid berlangsung untuk pertanyaan ini Bapak L. Dwi Efri Reza selaku Accounting Manajer menjelaskan bahwa "Untuk pendapatan secara umum tidak berpengaruh signifikan terhadap biaya opersional hotel termasuk didalamnya sistem pengajian karyawan, kami tetap melakukan seperti biasanya dalam arti sesuai dengan sebelum mewabahnya pandemic ini. Pada triwulan pertama pada tahun 2020 memang sempat terjadi lockdown untuk wilayah sembalun sebagai akibat kebijakan pemerintah terkait WFH selama hampir kurang lebih 3 bulan akan tetapi untuk menyiasatinya saya berkoordinasi dengan bagian Human Resorce Development dan General Manajer untuk keberlanjutan operasional hotel dari segi keuangan hotel mau tidak mau penerapan shifting bagi karyawan harus dijalankan agar tidak dapat berdampak buruk bagi keberlanjutan dari opersional hotel itu sendiri dan pada kesempatan tersebut diambilah keputusan terkait sistem shifting bagi karyawan untuk beberapa waktu kedepan sampai berakhirnya masa WFH".

Pada kesempatan yang sama juga peneliti menyakan terkait pendapatan hotel baik sebelum pandemic dan saat berlangsungnya pandemic ini, untuk pertanyaan ini marketing manager menjelaskan bahwa "Jika dilihat secara overall kita belum bisa menjawab apa-apa karena saat ini kita baru memasuki triwulan terakhir dari tahun 2020 dimana sistem pembukuan yang kami terapkan di hotel ini adalah dalam setiap triwulan tetapi jika dibandingkan antara dua triwulan terakhir pada tahun 2019 tepatnya bulan april sampai dengan desember dengan dua triwulan pertama pada tahun 2020 tepatnya pada bulan januari sampai dengan bulan September tingkat pendapatan hotel baik dari sisi penyewaan kamar dan restaurant tidak terlalu berdampak buruk terhadap kelangsungan hotel kami dalam arti terjadi penuruan pendapatan tapi tidak terlalu signifikan dibandingkan pendapatan pada tahun
2019 dimana jika kami mencoba mentotalitas sampai dengan bulan oktober ini tingkat penurunan dari segi pendapatan kami mengalami penuruan sekita $15-20 \%$ dari total pendapatan di tahun 2019. Tetapi untuk menutupi defisit $15-20 \%$ tersebut kami memiliki alokasi khusus yang memang sudah kami duga jika terjadi sesuatu hal dikemudian hari".

\section{Data Sekunder}

Data Sekunder merupakan data-data bersumber dari laporan-laporan atau dokumendokumen yang terkait, dimana data-data tersbut penulis dapatkan dari laporan keuangan yang diperoleh dari manajemen Rinjani Hills Hotel. Adapun data sekunder yang dapat disajikan pada peneltian ini merupakan data sewa kamar dan total pendapatan dalam rentang waktu enam bulan sebelum pandemic covid-19 dan enam bulan saat pandemic melanda dunia.

\section{Tingkat Hunian Rinjani Hill Hotel sebelum pandemic virus covid-19}

Data sekunder yang disajikan penulis adalah tingkat hunian kamar pada Rinjani Hill Hotel sebelum pandemic virus tepatnya periode oktober 2019 sampai dengan maret 2020.

Tabel 4.2: Tingkat hunian kamar dan pendapatan sebelum pandemi

\begin{tabular}{|c|l|l|l|}
\hline NO & \multicolumn{1}{|c|}{ BULAN } & $\begin{array}{c}\text { ROOM } \\
\text { SOLD }\end{array}$ & $\begin{array}{c}\text { PENDAPATAN } \\
(\text { Rp) }\end{array}$ \\
\hline 1 & Oktober & 50 & Rp. 14.950 .000 \\
\hline 2 & Nopember & 41 & Rp. 14.350 .000 \\
\hline 3 & Desember & 144 & Rp. 48.675 .000 \\
\hline 4 & Januari & 59 & Rp. 19.200 .000 \\
\hline 5 & Februari & 56 & Rp. 19.200 .000 \\
\hline 6 & Maret & 15 & Rp. 4.575 .000 \\
\hline & TOTAL & $\mathbf{3 6 5}$ & Rp. 101.750.000 \\
\hline
\end{tabular}

Sumber data: Rinjani Hill Hotel

Dari data tersebut terlihat bahwa dalam rentang waktu antara bulan oktober 2019 2sampai dengan maret 2020 jumlah kamar yang terjual sebanyak 365 kamar dengan total pendapatan Rp. 101.750.000-.

Tingkat Hunian Rinjani Hill Hotel saat pandemic virus covid-19 berlangsung

Data sekunder kedua yang penulis sajikan pada penelitian ini adalah tingkat hunian pada Rinjani Hill Hotel saat pandemic virus 
Jurnal Ilmu Sosial dan Pendidikan

http://ejournal.mandalanursa.org/index.php/JISIP/index

Terakreditasi Peringkat 5 (No. SK: 85/M/KPT/2020)

tepatnya periode april sampai dengan september 2020.

Tabel 4.3: Tingkat hunian kamar dan pendapatan saat pandemi

\begin{tabular}{|l|l|l|l|}
\hline NO & \multicolumn{1}{|c|}{ BULAN } & $\begin{array}{c}\text { ROOM } \\
\text { SOLD }\end{array}$ & \multicolumn{1}{|c|}{$\begin{array}{c}\text { PENDAPATAN } \\
\text { (Rp) }\end{array}$} \\
\hline 1 & April & 0 & Rp. 0 \\
\hline 2 & Mei & 0 & Rp. 0 \\
\hline 3 & Juni & 50 & Rp. 17.500 .000 \\
\hline 4 & Juli & 60 & Rp. 21.000 .000 \\
\hline 5 & Agustus & 61 & Rp. 21.350 .000 \\
\hline 6 & September & 72 & Rp. 22.450.000 \\
\hline \multicolumn{2}{|c|}{ TOTAL } & 243 & Rp. 82.300 .000 \\
\hline
\end{tabular}

Sumber data: Rinjani Hill Hotel

Dari data di atas terlihat bahwa dalam rentang waktu antara april sampai dengan september 2020 jumlah kamar yang terjual sejumlah 243 kamar dengan total pendapatan sebesar Rp. 82.300.000, dimana pada bulan april sampai dengan mei terjadi kekososngan hunian kamar yang diakibatkan pemberlakuannya lock down untuk wilayah sembalun dari pendatang luar.

\section{PEMBAHASAN}

Berdasarkan hasil observasi yang dilakukan oleh peneliti terhadap Rinjani Hill Hotel untuk melihat seberapa besar covid-19 dalam mempengaruhi tingkat pendapatan hotel diperoleh hasil bahwa covid-19 tidak berpengaruh signifikan terhadap pendapatan hotel dimana tingkat hunian kamar terlihat hanya beberapa kamar saja yang tidak ada pengunjungnya. Hal ini yang menjadi indikasi peneliti menyatakan bahwa covid-19 tidak terlalu berdampak terhadap pendapatan Sembalun Hills Hotel jika dilihat dari sisi hunian kamar. Disamping itu juga restaurant dan meeting room yang menjadi salah satu fasilitas hotel juga tidak terlalu sepi dimana dari hasil pengamatan melalui observasi lapangan peneliti melihat terdapat beberapa tamu yang silih berganti memasuki restaurant dari rinjani hill hotel. Hal ini juga senada dengan hasil wawancara peneliti dengan GM Rinjani Hill Hotel Bapak Lalu yang menyatakan bahwa "pendapatan hotel dari sisi hunian kamar dan restaurant sejak dihentikannya WFH tidak Jurnal Ilmu Sosial dan Pendidikan
Vol. 4. No. 4 November 2020 p-ISSN: 2598-9944 e- ISSN: 2656-6753

mengalami penurunan yang berarti hanya saja saat diberlakukannya WFH dan sempat disolasikan wilayah Sembalun dari pendatang luar pada saat itu terjadi penurunan kunjungan hotel yang sangat tajam bahkan mencapai 100\% selama 3 bulan berjalan akan tetapi semua itu dapat tertutupi sejak ditariknya kebijakan pemerintah terkait WFH". Adapun jumlah karywan pada Rinjani Hill Hotel berjumlah 20 orang karyawan. GM Rinjani Hill Hotel juga menambahkan bahwa "sejak terjadinya covid-19 bermacam strategi marketing hotel sudah mereka jalankan baik mulai dengan peningkatan kualitas layanan dengan menggunakan standar protokol kesehatan sangat berdampak terhadap kunjungan hotel dimana sejak berhentinya pemberlakukan WFH jumlah kunjungan hotel meningkat dibandingkan dengan jumah kunjungan hotel setiap bulan disaat sebelum terjadinya pandemic covid-19 hal ini tertentunya dapat membantu dalam menjalankan opersional hotel dan menutupi defisit dari pandapatan hotel disaat diberlakukannya WFH". Hal ini sejalan dengan survey yang dilakukan oleh perhimpunan hotel dan restaurant Indonesia yang menyatakan bahwa Mayoritas hotel berpendapat bahwa kinerja tingkat hunian kamar akan mengalami penurunan sekitar 25-50\% pada awal semester di tahun 2020 dibandingkan awal semester di tahun 2019. Dimana sekitar 25\% responden dari total $100 \%$ reponden berpendapat bahwa penurunan semester awal 2020 ini akan mencapai lebih dari 50\% dibandingkan dengan semester awal 2019. Hal ini membuktikan bahwa dari sisi pariwisata khususnya perhotelan lebih mengalami tekanan yang signifikan dari sisi tingkat hunian kamar dibandingkan dengan rata-rata harga kamar, dimana dalam hal ini disarankan bagi pengusaha yang bergerk dibidang perhotelan untuk menurunkan harga kamar untuk menstimulus tambahan jumlah kamar yang terjual selama pandemi virus ini masih berlangsung dengan demikian operasioan hotel sedikit tidak dapat berjalan untuk kelansungan kedepannya. 
Bagi Rinjani Hill Hotel, pendapatan memegang peranan penting dalam menentukan jalannya operasional hotel itu sendiri. Dimana dengan adanya pendapatan yang baik, operasional kegiatan dari hotel dapat berjalan dengan baik pula terlebih untuk pengembangan kedepannya demi mencapai tujuan pemasaran serta untuk mencapai tujuan hotel dalam menciptakan image hotel yang positif serta membangun mutual understanding, goodwill terhadap publik eksternal dan publik internal Rinjani Hill Hotel. Jika dilihat dari sisi marketing dimana marketing berfungsi sebagai public relation/humas dalam industri perhotelan dinyatakan sebagai suatu kegiatan komunikasi untuk mengembangkan citra yang baik, meningkatkan kredibilitas hotel, serta meningkatkan tingkat kepercayaan pelanggan hotel dengan cara membuat evaluasi dan menganalisis terkait pendapat pelanggan hotel khususnya yang berhubungan dengan layanan yang diberikan oleh pihak hotel, memberi masukan dan usul cara menangani pendapat, opini atau kritik yang ditujukan pada hotel, mempengaruhi pelanggan hotel melalui teknik komunikasi yang baik sehingga dapat meningkatkan image hotel yang lebih baik (Yoeti,2008)

\section{SIMPULAN}

Berdasarkan hasil observasi lapangan, penelitian dan pembahasan, maka dapat disimpulkan bahwa pada triwulan pertama sejak pandemi covid-19 menghantam Indonesia pada umumnya dan Lombok pada khusunya sangat berdampak terhadap operasioanl Rinjani Hill Hotel, akan tetapi sejak diberhentikannya Work From Home (WFH) tingkat kunjungan hotel mulai membaik dan terlihat ada peningkatan jumlah kunjungan dibandingkan bulan-bulan sebelum pandemic 19 mulai mewabah hal ini berdampak langsung dari sisi pendapatan hotel itu sendiri. Penerapan protocol kesehatan pada hotel merupakan salah satu cara didalam mempertahankan loyality konsumen.

\section{Saran}

Berdasarkan hasil observasi lapangan, penelitian dan pembahasaan peneliti dapat memberikan saran sebagai berikut:

1. Penerapan protocol kesehatan harus dimuali dari kesadaran individu masing-masing agar pandemic ini segera berakhir.

2. Dalam hal marketing mix perlu ditingkatkan disamping tetap mempertahankan customer relationship agar lolality konsumen tetap terjaga disaat pandemic ini masih berlangsung sehingga dapat meningkatkan kunjungan tamu hotel.

3. Bagi peneliti selanjutnya dapat melakukan penelitian tentang pendapatan hotel khusunya pada hotel kelas melati karena disetiap daerah memiliki perbedaan pendapatan terkait implikasi covid terhadap pendapatan hotel terutama hotel kelas melati

\section{DAFTAR PUSTAKA}

Afifudin, H., \& Saebani, B. A. (2009), Metodologi Penelitian Kualitatif, Bandung: CV. Pustaka Setia.

Agus Sulastiyono.(1999).Manajemen Penyelenggaraan Hotel.Bandung:Alfabeta

Damanik, Janianton dan Weber, Helmut.(2006). Perencanaan Ekowisata Dari Teori Ke Aplikasi. Yogyakarta: PUSPAR UGM dan Andi

Fess,Reeve,Warren.(2005).Pengantar

Akuntansi.Jakarta : Salemba Empat

Grolier Electronic Publishing Inc.(1995).

Pitana.I.Gde dan Gayatri,Putu G. (2005).SosiologiPariwisata.Yogyakart a:Andi

Sugiyono.(2013).Metode Penelitian

Bisnis.Bandung:Alfabeta

Sugiyono.(2009).Metode Penelitian Kuantitatif, Kualitatif, dan R \&D .Bandung: Alfabeta

Suwardjono.(2008).Teori Akuntansi:

Perekayasaan Pelaporan

Keuangan.Yogyakarta : BPFE 
Undang-Undang Republik Indonesia No.10 Tahun 2009 Tentang Kepariwisataan.

Wiyasha.I.B.M.(2010) Akuntansi Perhotelan.Yogyakarta :Andi Offset

Yin, R. K. (2002), Studi Kasus Desain dan Metode, Terjemahan, M. D. Mudzakir, Jakarta: PT RajaGrafindo Persada.

Yoeti,Oka A.(2008).Perencanaan Dan Pengembangan Pariwisata. Jakarta : Pradnya Paramita .(1997). Perencanaan Dan Pengembangan Pariwisata. Jakarta : Pradnya Paramita

Website:

https://id.wikipedia.org/wiki/Pandemi_koronavi rus_di_Indonesia www.majalahpendidikan.com www.majalahpendidikan.com www.pariwisata dan teknologi.blogspot.com www.rafans detik.blogdetik.com 